\title{
Announcements Book Review
}

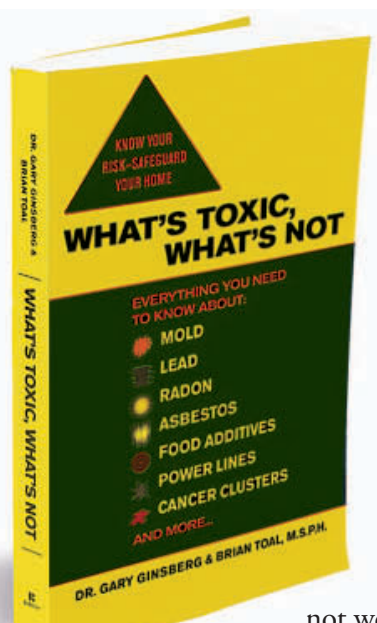

not well informed.

The book is organized around toxicants at home and

work (lead, radon, mold, asbestos), toxicants we eat, drink, or buy at the store (toxicants in food, water pollution, consumer products), toxicants in air (indoor and outdoor), and toxicants in the yard and neighborhood (garden, power lines, hazardous waste sites, volatile organics), and the authors also provide an informative section on cancer clusters.

Ginsberg and Toal use several tools very effectively in presenting their message. They rank each toxicant in terms of toxicity, exposure, and risk on a scale of 0 to 100 , and this helps put the relative risk of this diverse group of agents in perspective. This ranking is particularly valuable for what they call "toxic uncertainties," such as fluoride in drinking water, electromagnetic fields (EMFs), phthalates, polybrominated diphenyl ethers, and perfluorooctane sulfonate, where exposure is widespread but where the magnitude of toxicity is still a matter of debate. The authors list a series of questions and helpful answers, such as "This job is toxic: who can I call?" with the answer being to start with your employer, and if that doesn't work to go to the Occupational Safety and Health Association (OSHA) website or state occupational health unit. They list the top 10 toxic myths (for example, the myth is that mold is a sign of poor housekeeping) and the realities (in this case, mold will grow wherever there is moisture) for specific toxics. The end of each chapter provides advice on how to determine whether you are exposed and, if so, steps that can be taken to reduce exposure. These are very effective ways to communicate important information.

As with any text that tries to make things easily understood and simple, in some areas important information is lost. The table stating that there are no adverse health effects of lead $<10 \mu \mathrm{g} / \mathrm{dL}$ is not accurate, despite the current position of the Centers for Disease Control and Prevention, and the statement that only lead levels of $40 \mu \mathrm{g} / \mathrm{dL}$ are dangerous is even less correct. There is no mention of the dangers of lead to adults, only warnings that adults should not bring lead home from their jobs and expose their children. The section on fish consumption references studies that I and my colleagues have conducted on contaminants in farmed salmon, and mistakenly states that dioxins are the major contaminant of concern, whereas it is polychlorinated biphenyls, dieldrin, and toxaphene, not dioxin, that drive the fish consumption advisories. In addition, the book recommends one meal of farm-raised salmon per week for women and children, whereas our results indicate elevated cancer risk from one meal or even less per month. The excellent chapter on EMF mentions only high-voltage power lines, even though the most common exposure comes from distribution lines. And there is no discussion of radiofrequency (cell phone) EMFs, a subject of considerable current interest.

These are minor issues, however, in what is an excellent and very readable book on the toxics in our environment. This book should find a place in every home. When it doesn't answer all of the questions, it provides reference to sources that will. It is a wonderful resource that physicians and environmental health personnel can provide to patients and the public for easily understood information on exposures of concern to the community.

\section{DAVID O. CARPENTER}

David O. Carpenter is the former dean of the School of Public Health, and is currently the director of the Institute for Health and the Environment at the University at Albany. His major area of research is human health effects of environmental contaminants.

\section{Announcements New Books}

\author{
Air Pollution XIV \\ J.W.S. Longhurst, ed. \\ Billerica, MA:WITpress, 2006. $824 \mathrm{pp}$ \\ ISBN: 1-84564-165-5, \$423 \\ Chemicals as Intentional and Accidental \\ Global Environmental Threats \\ Lubomir Simeonov, Elisabeta Chirila, eds. \\ New York:Springer, 2006. 514 pp. \\ ISBN: 1-4020-5096-8, \$219 \\ Chernobyl-What Have We Learned? \\ Yasuo Onishi, Oleg V. Voitsekhovich, \\ Mark J. Zheleznyak, eds. \\ New York:Springer, 2006. 289 pp. \\ ISBN: $1-4020-5348-7, \$ 129$ \\ Comparative Environmental Politics \\ Jerry McBeath, Jonathan Rosenberg \\ New York:Springer, 2006. 193 pp. \\ ISBN: 1-4020-4762-2, \$125 \\ Energy and Culture: Perspectives on \\ the Power to Work \\ Brendan Dooley \\ Burlington, VT:Ashgate, 2006. 264 pp. \\ ISBN: 0-7546-4514-2, \$114.95 \\ Fluoride in Drinking-water \\ J. Fawell, K. Bailey, J. Chilton, E. Dabl, et al. \\ Geneva:WHO Press, 2006. 144 pp. \\ ISBN: 9241563192, \$63
}

Fluorine and the Environment

Alain Tressaud, ed.

Burlington, MA:Elsevier, 2006. 296 pp. ISBN: 0-444-52672-2, \$165

Generation Extra Large: Rescuing Our Children from the Epidemic of Obesity Chris Woolston, Lisa Tartamella, Elaine Herscher New York:Perseus Books Group, 2006. 255 pp. ISBN: 0-465-08391-9, \$14.95

Governance of Biodiversity: Conservation in China and Taiwan Gerald A. McBeath, Tse-Kang Leng Northampton, MA: Edward Elgar Publishing, 2006. 256 pp. ISBN: 1-84376-810-0, \$99

Growing Smarter: Achieving Livable Communities, Environmental Justice and Regional Equity Robert D. Bullard, ed. Cambridge, MA:MIT Press, 2006. 408 pp. ISBN: 0-262-02610-4, \$67

Health of the People: The African Regional Health Report World Health Organization Geneva:WHO Press, 2006. 196 pp. ISBN: 929-023103-3, \$27
Health Risks from Dioxin and Related Compounds: Evaluation of the EPA Reassessment

Committee on EPA's Exposure and Human Health Reassessment of TCDD and Related Compounds, National Research Council Washington, DC:National Academies Press, 2006. 268 pp. ISBN: 0-309-10258-8, \$54

Politics of Oil: A Survey

Bulent Gokay, ed.

Oxford, UK:Routledge, 2006. 260 pp.

ISBN: 1-8574-3340-8, $\$ 230$

Protecting Ground Water for Health

World Health Organization

Geneva:WHO Press, 2006. 697 pp.

ISBN: 924-154668-9, \$144

Reality Check: The Nature and

Performance of Voluntary

Environmental Programs in the United

States, Europe, and Japan

Richard D. Morgenstein, William A. Pizer, eds.

Washington, DC:RFF Press, 2006. 200 pp

ISBN: 1-933115-36-X, $\$ 80$
Solar Revolution: The Economic Transformation of the Global Energy Industry

Travis Bradford

Cambridge, MA:MIT Press, 2006. 248 pp. ISBN: 0-262-02604-X, \$24.95

Sustainable Nuclear Power Galem Suppes, Truman Storvick Burlington, MA:Elsevier, 2006. 416 pp. ISBN: 0-12-370602-5, \$59.95

Sustainability or Collapse? Robert Costanza, Lisa J. Graumlich, Will Steffen, eds. Cambridge, MA:MIT Press, 2006. 520 pp. ISBN: 0-262-03366-6, \$38

Why Care for Nature?

Dirk Willem Postma

New York:Springer, 2006. 221 pp.

ISBN: 1-4020-5002-X, \$129 